\title{
Evaluasi Performa Kelembagaan Peternak Sapi Perah Berdasarkan Aspek Risiko Bisnis dan Pengembangan Usaha
}

\author{
Amam $^{1,2 *}$ dan Soetriono ${ }^{2}$ \\ ${ }^{1}$ Program Studi Peternakan, Dept. Agronomi, Fakultas Pertanian, Universitas Jember \\ ${ }^{2}$ Program Studi Agribisnis, Dept. Sosial Ekonomi, Fakultas Pertanian, Universitas Jember \\ J1. Kalimantan No. 37, Jember Jawa Timur \\ *Email korespondensi: amam.faperta@unej.ac.id
}

(Diterima: 22-10-2018; disetujui 25-11-2018)

\begin{abstract}
ABSTRAK
Peranan kelembagaan peternakan bukan hanya untuk tindakan preventif bagi para peternak untuk meminimalkan risiko bisnis, tetapi juga bertujuan untuk pengembangan usaha ternak sebagai upaya dalam mendukung kesejahteraan masyarakat. Penelitian bertujuan untuk: 1) mengevaluasi performa kelembagaan peternak sapi perah berdasarkan aspek risiko bisnis, 2) mengevaluasi performa kelembagaan peternak sapi perah berdasarkan pengembangan usaha, dan 3) menemukan model hubungan performa kelembagaan, pengembangan usaha, dan aspek risiko bisnis. Penelitian dilakukan di Kecamatan Pujon, Kabupaten Malang, Provinsi Jawa Timur. Variabel yang diamati dalam penelitian post positivisme ialah: a) performa kelembagaan $\left.\left(\mathrm{X}_{1}\right), \mathrm{b}\right)$ aspek risiko bisnis $\left(\mathrm{Z}_{1}\right)$, dan $\left.\mathrm{c}\right)$ pengembangan usaha ternak perah $\left(\mathrm{Y}_{1}\right)$. Jumlah sampel penelitian yaitu 119 peternak sapi perah. Analisis data menggunakan SEM (Structural Equation Model) dengan SmartPLS 2.0. Hasil penelitian yaitu: 1) performa kelembagaan berpengaruh negatif terhadap risiko bisnis usaha ternak sapi perah sebesar $-0,337$; 2) performa kelembagaan berpengaruh positif terhadap pengembangan usaha ternak sapi perah sebesar 0,442; dan 3) aspek risiko bisnis dipengarui oleh performa kelembagaan sebesar $22,0 \%$, sedangkan aspek risiko bisnis dipengaruhi oleh performa kelembagaan dan pengembangan usaha sebesar 19,6\%. Pengembangan usaha berpengaruh negatif terhadap risiko bisnis usaha ternak sapi perah sebesar $-0,210$.
\end{abstract}

Kata kunci: evaluasi, kelembagaan, pengembangan usaha, risiko bisnis, dan sapi perah.

\begin{abstract}
The role of livestock institutional is not only for preventive actions for farmers to minimize business risk, but also for the development of livestock business in an effort to support the welfare of the community. The research aims to: 1) evaluate the performance of dairy farmer based on business risk aspect, 2) evaluate the performance of dairy farmer based on business development, and 3) find the relation of business risk aspect to business development. The study was conducted in Pujon Subdistrict, Malang Regency, East Java Province. The variables observed in post positivism research are: a) institutional performance $\left.\left(\mathrm{X}_{1}\right), \mathrm{b}\right)$ business risk aspect $\left(\mathrm{Z}_{1}\right)$, and c) dairy business development $\left(\mathrm{Y}_{1}\right)$. The number of research sample is 119 dairy farmers. Data analysis uses SEM (Structural Equation Model) with SmartPLS 2.0. The research results are: 1) the institutional performance was negative influenced by the business risk aspect by $-0.337 ; 2$ ) institutional performance was positive influenced bythedairy cattle business development by 0.442 ; and 3) aspects of business risk was influenced by the institutional performance is $22.0 \%$, while aspects of business risk was influenced by the institutional performance and the business development is $19.6 \%$. the dairy cattle business development was negative influenced by the business risk aspects by -0.210 .
\end{abstract}

Keyword: evaluation, institutional, development livestock business, risk of business, and dairy cattle. 


\section{PENDAHULUAN}

Peranan kelembagaan peternakan bukan hanya untuk tindakan preventif bagi para peternak untuk meminimalkan risiko bisnis, tetapi juga bertujuan untuk pengembangan usaha ternak sebagai upaya dalam mendukung kesejahteraan masyarakat. Seiring dengan meningkatnya kebutuhan dan permintaan susu segar di Indonesia, upaya pengembangan usaha ternak sapi perah terus dicanangkan oleh pemerintah. Berbagai upaya pengembangan usaha ternak sapi perah telah dilakukan pemerintah diantaranya program Inseminasi Buatan (IB), penyuluhan peternakan, sosialisasi manajemen pemeliharaan sapi perah, dan bekerjasama dengan koperasi terkait pengadaan sarana produksi ternak (sapronak). Sejalan dengan upaya pengembangan usaha ternak, aspek risiko bisnis juga semakin besar. Risiko bisnis tersebut diantaranya rendahnya harga jual susu segar, mahalnya sumber pakan konsentrat, dan sulitnya akses hijauan pakan saat musim kemarau.

Salah satu fungsi kelembagaan untuk meminimalkan risiko bisnis bagi peternak sapi perah. Fungsi tersebut diantaranya yaitu dengan adanya kelembagaan atau kelompok peternak, maka peternak sapi perahdilatih untuk mengolah susu segar saat harga jual susu segar turun, misalnya untuk olahan susu pasteurisasi, permen susu, dan es krim. Salah satu fungsi kelembagaan untuk pengembangan usaha ternak sapi perah. Fungsi tersebut diantaranya yaitu dengan adanya kelembagaan atau kelompok peternak, maka peternak sapi perah bisa mendapatkan sapronak berupa pakan konsentrat yang nanti ditukar dengan penjualan susu segar, sehingga secara teknis dan teori, performa kelembagaan peternak sapi perah dipengaruhi oleh aspek risiko bisnis dan pengembangan usaha. Haloho et al. (2013) menyatakan bahwa input faktor produksi secara serempak berpengaruh nyata terhadap keuntungan peternak.

Kelembagaan peternak sapi perah yang sudah terbentuk dan dijadikan obyek penelitian ialah Kecamatan Pujon, Kabupaten Malang. Lokasi tersebut merupakan kawasan pengembangan sapi perah di Jawa Timur dengan total populasi 18.327 ekor (Kopsae, 2017). Bentuk kelembagaan peternak sapi perah di Kecamatan Pujon ialah Koperasi SAE Pujon yang resmi berdiri tahun 1968. Wujud keberadaan koperasi tersebut bagi peternak dan masyarakat sekitar ialah akses simpan pinjam modal usaha ternak sapi perah, penyediaan sapronak berupa kawin suntik (IB), industri pengolahan susu segar, dan pakan konsentrat untuk optimalisasi penggemukan yang berdampak pada peningkatan pendapatan peternak (Setiawan et al., 2013).

Tujuan penelitian ini yaitu: 1) mengevaluasi performa kelembagaan peternak sapi perah berdasarkan aspek risiko bisnis, 2) mengevaluasi performa kelembagaan peternak sapi perah berdasarkan pengembangan usaha, dan 3) menemukan model hubungan performa kelembagaan, pengembangan usaha, dan aspek risiko bisnis.

\section{METODE PENELITIAN}

\section{Waktu dan Lokasi Penelitian}

Penelitian dilakukan bulan Maret sampai Mei 2018. Lokasi penelitian dipilih secara puposif di Kecamatan Pujon, Kabupaten Malang. Lokasi tersebut dipilih dengan pertimbangan bahwa jumlah peternak yang ada di Kecamatan Pujon sebanyak 5.527 orang dengan jumlah populasi sapi perah sebanyak 20.670 ekor (BPS, 2017). Kecamatan Pujon merupakan kecamatan dengan jumlah populasi sapi perah terbanyak di Jawa Timur.

\section{Populasi Penelitian}

Perhitungan sampel berdasarkan teori Amora yaitu 5-10 kali jumlah variabel yang digunakan dalam penelitian (Amam dkk, 2017). Jumlah sampel yang digunakan dalam penelitian ialah 17 variabel, yang teridiri dari: a) performa kelembagaan, b) aspek risiko bisnis, dan c) pengembangan usaha ternak sapi perah. Berdasarkan teori Amora, sampel yang digunakan dalam penelitian yaitu:

$$
17 \text { variabel x } 7=119 \text { sampel }
$$

\section{Pengumpulan Data}

Data diperoleh dari kuisioner dengan skala likert yang diberikan kepada responden, metode wawancara dan pengamatan langsung digunakan untuk mengetahui dan mengukur indikator dan variabel. Jenis data dibagi menjadi data primer dan data sekunder. Data primer didapat langsung dari responden, sedangkan data sekunder diperoleh dari arsip data di Koperasi SAE Pujon, data di Kecamatan Pujon, data BPS, data Dinas Peternakan Kabupaten Malang, dan data lain yang mendukung penelitian. 


\section{Variabel Penelitian}

Penelitian ini terdiri dari 3 variabel laten dan 17 indikator pembentuk variabel manifest. Variabel tersebut yaitu:

Tabel 1. Variabel dan indikator

\begin{tabular}{|l|c|}
\hline Indikator Performa Kelembagaan $\left(\mathrm{X}_{1}\right)$ & Notasi \\
\hline sarana kelompok peternak & $\mathrm{X}_{1.1}$ \\
\hline capaian tujuan kelompok & $\mathrm{X}_{1.2}$ \\
\hline fungsi dan tugas kelompok & $\mathrm{X}_{1.3}$ \\
\hline struktur kelompok & $\mathrm{X}_{1.4}$ \\
\hline kerukunan kelompok & $\mathrm{X}_{1.5}$ \\
\hline bentuk kelembagaan kelompok & $\mathrm{X}_{1.6}$ \\
\hline Indikator Pengembangan Usaha $\left(\mathrm{Z}_{1}\right)$ & Notasi \\
\hline bertambahnya pendapatan & $\mathrm{Z}_{1.1}$ \\
\hline bertambahnya populasi & $\mathrm{Z}_{1.2}$ \\
\hline bertambahnya tenaga kerja & $\mathrm{Z}_{1.3}$ \\
\hline bertambahnya unit produksi (kandang) & $\mathrm{Z}_{1.4}$ \\
\hline Indikator Aspek Risiko Bisnis (Y $\left.{ }_{1}\right)$ & $\mathrm{Notasi}$ \\
\hline musim (kondisi tidak normal) & $\mathrm{Y}_{1.1}$ \\
\hline keamanan (tingkat pencurian ternak) & $\mathrm{Y}_{1.2}$ \\
\hline penyakit ternak & $\mathrm{Y}_{1.3}$ \\
\hline fluktuasi harga susu & $\mathrm{Y}_{1.4}$ \\
\hline kebijakan pemerintah & $\mathrm{Y}_{1.5}$ \\
\hline $\begin{array}{l}\text { kebijakan kelompok peternak } \\
\text { (kelembagaan peternak) }\end{array}$ & $\mathrm{Y}_{1.6}$ \\
\hline moralitas peternak dalam kelompok & $\mathrm{Y}_{1.7}$ \\
\hline
\end{tabular}

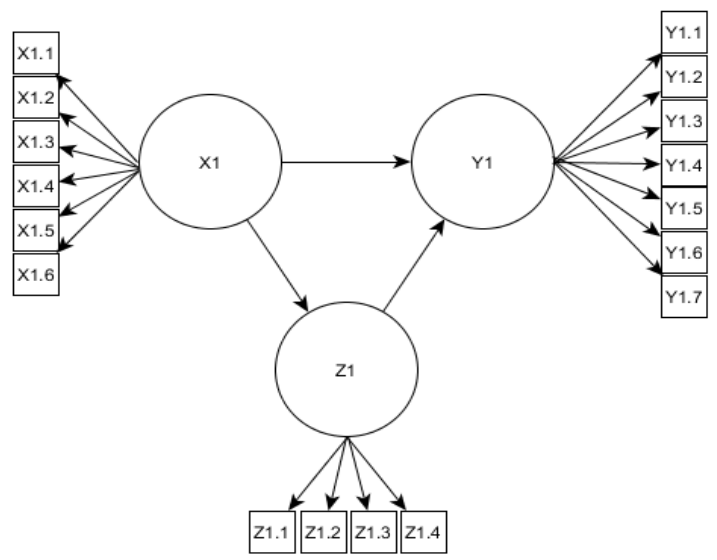

Gambar 1. Model Hubungan Variabel

\section{Analisis Data}

Structural Equation Model (SEM) dengan SmartPLS 2.0. digunakan untuk menjawab hipotesis 1, 2, dan 3, yaitu: 1) performa kelembagaan yang dipengaruhi oleh aspek risiko bisnis, 2) performa kelembagaan yang dipengaruhi oleh pengembangan usaha ternak sapi perah, dan 3) hubungan aspek risiko bisnis dengan pengembangan usaha ternak sapi perah. Penggunaan SmartPLS 2.0. juga dapat mengetahui hubungan beberapa variabel dalam dua arah, sehingga mempermudah peneliti dalam menemukan teori baru atau memperkuat teori yang lemah (Wiyono, 2012).

\section{HASIL PENELITIAN}

\section{Uji Indikator}

Indikator pendukung variabel utama diuji menggunakan SmartPLS 2.0. dan didapatkan hasil sebagai berikut:

Tabel 2. Nilai outer loading

\begin{tabular}{|c|c|c|c|c|}
\hline & $\mathrm{X}_{1}$ & $\mathrm{Z}_{1}$ & $\mathrm{Y}_{1}$ & Result \\
\hline $\mathrm{X}_{1.1}$ & .533 & & & valid \\
\hline $\mathrm{X}_{1.2}$ & .733 & & & valid \\
\hline $\mathrm{X}_{1.3}$ & .889 & & & valid \\
\hline $\mathrm{X}_{1.4}$ & .800 & & & valid \\
\hline $\mathrm{X}_{1.5}$ & -.486 & & & tidak valid \\
\hline $\mathrm{X}_{1.6}$ & .415 & & & tidak valid \\
\hline $\mathrm{Z}_{1.1}$ & & .309 & & tidak valid \\
\hline $\mathrm{Z}_{1.2}$ & & .425 & & tidak valid \\
\hline $\mathrm{Z}_{1.3}$ & & .581 & & valid \\
\hline $\mathrm{Z}_{1.4}$ & & .898 & & valid \\
\hline $\mathrm{Y}_{1.1}$ & & & .315 & tidak valid \\
\hline $\mathrm{Y}_{1.2}$ & & & .380 & tidak valid \\
\hline $\mathrm{Y}_{1.3}$ & & & .667 & tidak valid \\
\hline $\mathrm{Y}_{1.4}$ & & & .849 & valid \\
\hline $\mathrm{Y}_{1.5}$ & & & .811 & valid \\
\hline $\mathrm{Y}_{1.6}$ & & & .848 & valid \\
\hline $\mathrm{Y}_{1.7}$ & & & .795 & valid \\
\hline
\end{tabular}

Nilai Outer Loadings yang memenuhi syarat ialah lebih dari 0,500 . Data pada Tabel 2 menunjukkan bahwa hasil uji indikator variabel performa kelembagaan yang memenuhi syarat ialah: a) sarana kelompok peternak, b) capaian tujuan kelompok, c) fungsi dan tugas kelompok, serta d) struktur kelompok. Hasil uji indikator pengembangan usaha ternak sapi perah yang memenuhi syarat ialah: a) bertambahnya tenaga kerja yang dibayar dan b) bertambahnya kandang (unit produksi). Hasil uji indikator aspek risiko bisnis yang memenuhi syarat ialah: a) fluktuasi harga susu, b) kebijakan pemerintah, c) kebijakan kelompok peternak, dan d) moralitas peternak dalam kelempok.

\section{Uji Struktural}

Uji struktural terdiri dari nilai Composite Reliability (CR), nilai $\mathrm{R}$ Square $\left(\mathrm{R}^{2}\right)$, dan nilai Cronbach's Alpha (CA), masing-masing nilai tersebut didapatkan hasil sebagai berikut:

Tabel 3. Uji Struktural

\begin{tabular}{|c|r|r|r|}
\hline & \multicolumn{1}{|c|}{ CR } & $\mathrm{R}^{2}$ & CA \\
\hline $\mathrm{X}_{1}$ & 0.833 & & 0.743 \\
\hline $\mathrm{Z}_{1}$ & 0.895 & 0.220 & 0.851 \\
\hline $\mathrm{Y}_{1}$ & 0.718 & 0.195 & 0.281 \\
\hline
\end{tabular}

Uji struktural pada uji pengaruh atau uji hipotesis setelah uji indikator terdiri dari nilai koefisien determinasi $\left(\mathrm{R}^{2}\right)$, nilai t-statistik, dan 
nilai koefisien parameter, masing-masing nilai tersebut didapatkan hasil sebagai berikut:

Tabel 4. Uji model

\begin{tabular}{|l|c|}
\hline \multicolumn{1}{|c|}{ Pengujian } & Hasil Uji \\
\hline Koefisien Determinasi $\mathrm{R}^{2}$ & \\
Aspek Risiko Bisnis & 0.220 \\
Pengembangan Usaha & 0.196 \\
\hline T-statistik & 4.723 \\
$\mathrm{X}_{1} \rightarrow \mathrm{Y}_{1}$ & 3.216 \\
$\mathrm{Z}_{1} \rightarrow \mathrm{Y}_{1}$ & 7.146 \\
$\mathrm{X}_{1} \rightarrow \mathrm{Z}_{1}$ & \\
\hline Koefisien Parameter & -0.337 \\
$\mathrm{X}_{1} \rightarrow \mathrm{Y}_{1}$ & -0.210 \\
$\mathrm{Z}_{1} \rightarrow \mathrm{Y}_{1}$ & 0.442 \\
$\mathrm{X}_{1} \rightarrow \mathrm{Z}_{1}$ & \\
\hline
\end{tabular}

Sumber: Data diolah (2018)

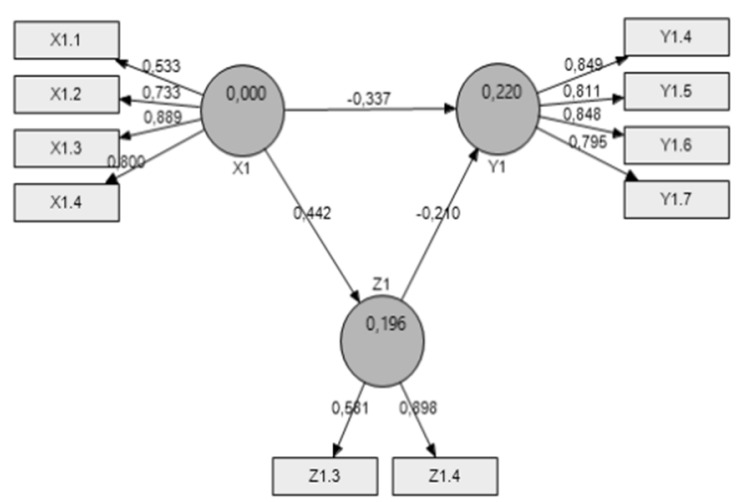

Gambar 2. Hasil Algoritma PLS

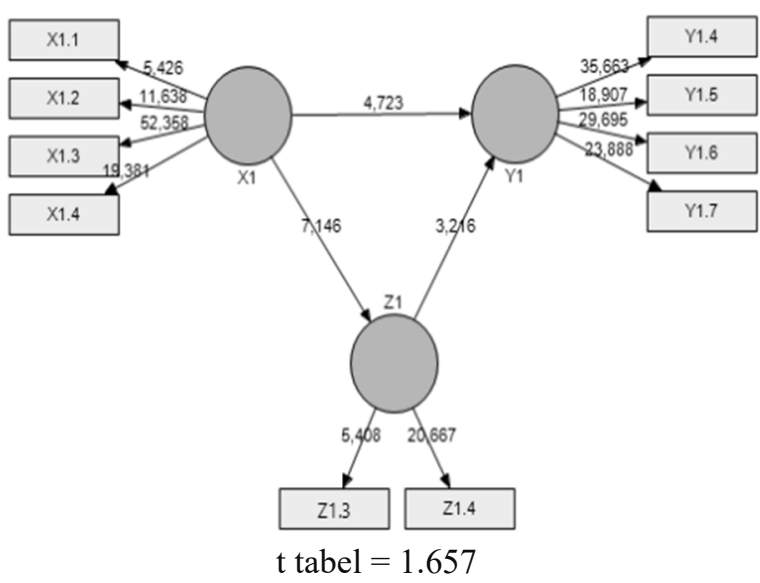

Gambar 3. Hasil Bootstraping PLS

\section{PEMBAHASAN}

\section{Evaluasi Performa Kelembagaan pada Aspek Risiko Bisnis}

Performa kelembagaan peternak sapi perah berpengaruh nyata terhadap risiko bisnis sebesar -0.337 , artinya terdapat pengaruh negatif dari performa kelembagaan terhadap risiko bisnis usaha ternak sapi perah.Semakin besar performa kelembagaan peternak, maka semakin kecil peluang peternak mengalami risiko bisnis usaha ternak sapi perah. Hal tersebut menunjukkan bahwa peranan kelembagaan sangat penting untuk mensejahterakaan peternak.

Mukson et al. (2012) menyatakan bahwa sosial, ekonomi, kelembagaan, dan lingkungan usaha perlu diperhatikan dalam upaya untuk meningkatkan produktivitas usaha dan pendapatan peternak. Hermanto (2018) menyebutkan bahwa tantangan pertanian di masa depan lebih kompleks, sehingga harus ada perpaduan antara teknologi dan inovasi, penyempurnaan kebijakan, dan penguatan kelembagaan pertanian.

Kalangi et al. (2014) menyebutkan bahwa peranan kelompok tani harus ditingkatkan, sebab salah satu tujuannya untuk memfasilitasi perdagangan pakan ternak dan penyediaan kredit bagi peternak, serta meningkatkan posisi tawar peternak (Nasrul, 2012), selain itu peternak juga mampu meningkatkan penerimaan dengan menggunakan konsep integrasi tanaman dengan ternak (Tawaf et al., 2016) atau melakukan pembibitan sendiri sebagai langkah investasi awal (Perilla et al., 2009).

Aspek risiko bisnis pada fluktuasi penjualan harga susu segar berdampak kesejahteraan peternak, sehingga menurut Indarsih et al. (2010) menyatakan bahwa diperlukan keterlibatan pemerintah untuk mendorong investor baru untuk mengatasi ketidakstabilan harga, dan hal tersebut akan berdampak pada akses peternak terhadap berbagai macam sumber daya (Mukson et al., 2017) dari mulai prapoduksi, pemasaran, dan jasa penunjang (Prasetyo et al., 2012).

\section{Evaluasi Performa Kelembagaan pada Pengembangan Usaha}

Performa kelembagaan peternak sapi perah berpengaruh nyata terhadap pengembangan usaha sebesar 0.442 , artinya terdapat pengaruh positif dari performa kelembagaan terhadap pengembangan usaha ternak sapi perah. Semakin besar performa kelembagaan peternak, maka semakin besar peluang peternak untuk mengembangkan usaha ternak sapi perah. Roessali et al. (2011) menyebutkan bahwa keputusan petani untuk untuk meningkatkan skala usaha ternaknya dipengaruhi secara positif signifikan oleh tingkat keterlibatan tenaga kerja keluarga dan harapan peternak, sedangkan menurut Riszqina et al. (2014) menyatakan bahwa keterampilan tenaga kerja yang disertai motivasi, berpengaruh nyata terhadap 
produktivitas usaha, sehingga perlu adanya pembinaan dan pendampingan.

Pembinaan dan pendampingan kelompok tani juga bisa dilakukan oleh Penyuluh Pertanian Lapangan (PPL), atau organisasi lain yang dianggap mampu untuk dilibatkan dalam usaha penguatan kelompok tani dalam pemberdayaan (Ramdhani dkk, 2012). Kelompok tani yang baik menurut Rustandi dan Suhadji (2017) yaitu mampu menjalankan fungsinya sebagai kelas belajar, wahana untuk bekerjasama, dan sebagai unit produksi, sehingga peran penyuluh dan tokoh masyarakat sebagai motivator masih dominan di masyarakat (Indraningsih, 2018).

Anantanyu (2011) menyatakan bahwa keberadaan kelembagaan petani sudah menjadi keniscayaan supaya memperbaiki taraf hidup, harkat, dan martabat petani Indonesia. Kelembagaan pertanian harus ditempatkan sebagai sarana untuk mewujudkan harapan, keinginan, dan pemenuhan kebutuhan para petani, sehingga kelembagaan yang efektif diharapkan mampu memberi kontribusi nyata dalam peningkatan kemandirian petani.

Kelembagaan pertanian menurut Djalil (2016) sejatinya sudah ada puluhan tahun silam, sebagai upaya pemberdayaan masyarakat petani, namun keberadaan tersebut belum mampu meningkatkan nilai tambah produk (NTP), padahal menurut Suswandi dan Sutarno (2017) menjelaskan bahwa dinamika kelompok tani yang baik, terlihat dari kuatnya faktor-faktor kekuatan yang mampu menggerakkan perilaku anggota kelompok untuk mencapai tujuan secara efektif dan efisien.

\section{Model Hubungan Performa Kelembagaan, Pengembangan Usaha, dan Aspek Risiko Bisnis}

Pengembangan usaha ternak sapi perah berpengaruh nyata terhadap risiko bisnis sebesar -0.210 , artinya terdapat pengaruh negatif dari pengembangan usaha terhadap risiko bisnis usaha ternak sapi perah. Semakin besar pengembangan usaha peternak, semakin kecil peluang peternak mengalami risiko bisnis usaha ternak sapi perah.

Asmara et al. (2017) menyebutkan bahwa produktivitas dan profitabilitas peternakan skala besar lebih tinggi dibandingkan dengan peternakan skala kecil dan Riszqina et al. (2014) menyebutkan bahwa skala usaha berpengaruh sangat terhadap produktivitas ternak, oleh sebab itu Burhanuddin et al. (2013) menyatakan bahwa Indonesia masih membutuhkan sekitar 4 juta wirausaha untuk menjadi negara maju yang didukung oleh inovasi, produksi, daya saing, risiko, tenaga kerja, kebijakan, dan aktivitas kewirausahaan.

Hal tersebut terjadi karena jumlah populasi ternak, manajemen pemberian pakan, dan penguasaan teknologi peternak dirasa belum optimal (Sumekar et al., 2013), terutama melakukan efisiensi biaya produksi seperti pakan dan obat-obatan (Pakage et al., 2015), sehingga risiko pembibitan, sanitasi, perawatan kesehatan ternak, dan manajemen pemberian pakan tidak menghambat pengembangan usaha (Septiani et al., 2017).

\section{KESIMPULAN}

Performa kelembagaan berpengaruh negatif terhadap risiko bisnis usaha ternak sapi perah sebesar -0,337. Performa kelembagaan berpengaruh positif terhadap pengembangan usaha ternak sapi perah sebesar 0,442. Aspek risiko bisnis dipengaruhi oleh performa kelembagaan sebesar 22,0\%, sedangkan aspek risiko bisnis dipengaruhi oleh performa kelembagaan dan pengembangan usaha sebesar $19,6 \%$. Pengembangan usaha berpengaruh negatif terhadap risiko bisnis usaha ternak sapi perah sebesar -0,210.

\section{DAFTAR PUSTAKA}

Anantanyu, S. 2011. Kelembagan petani: peran dan strategi pengembangan kapasitasnya. Jurnal SEPA 7 (2):102-109.

Asmara, A., Y.L. Purnamadewi \& D. Lubis. 2017. The relationship analysis between service performances of milk producer cooperative with the dairy farm performance of members. Media Peternakan 40(2):143-150.

Burhanuddin, Harianto, R. Nurmalina \& R. Pambudy. 2013. The determining factors of entrepreneurial activity in broiler farms. Media Peternakan 36 (3):230-236.

Djalil, B. 2016. Model penguatan lembaga petani sebagai prime mover nilai tambah produk pertanian. Jurnal Lentera 14(2): 265-278.

Hermanto. 2018. Pengentasan kemiskinan di perdesaan: pengembangan SDM, penguatan usaha, dan inovasi pertanian. Forum Penelitian Agro Ekonomi 35(2): 139-150.

Indarsih, B., M.H. Tamsil, \& M.P. Nugroho. 2010. A Study of Contract Broiler 
Production in Lombok, NTB: An Opportunity of Introducing Syari'ah Partnership. Media Peternakan 33 (2):124130.

Indraningsih, K.S. 2018. Strategi diseminasi inovasi pertanian dalam mendukung pembangunan pertanian. Forum Penelitian Agro Ekonomi 35(2):107-123.

Kalangi, L.S., Y. Syaukat, S.U. Kuntjoro, \& A. Priyanti. 2014. Technical efficiency of beef cattle breeding business in East Java province. Media Peternakan 37(2):136142.

Mukson, M. Isbandi, S.I. Santosa, Sudjadmogo, \& A. Setiadi. 2012. Analysis of various factors in order to enhance productivity and income of diary cattle farmers in Central Java, Indonesia. JITAA 37(3): 220-208.

Mukson, M., H. Setiawan, M. Handayani, \& A. Setiadi. 2017. Analysis of the local resource-based dairy cattle development in Central Java. JITAA 42(1):48-56.

Nasrul, W. 2012. Pengembangan kelembagaan pertanian untuk meningkatkan kapasitas petani terhadap pembangunan pertanian. Jurnal Menara Ilmu. 3 (29):166-174.

Pakage, S., B. Hartono, Z. Fanani, \& B.A. Nugroho. 2015. Analysis of technical, allocative and economic efficiency of broiler production using closed house system in malang district of East Java, Indonesia. LRRD 27(9):1-8.

Perilla, M.V., J.M. Escala, \& A. Setiadi. 2009. A Case Study of Luntian multi-purpose cooperative in barangay lalaig, tiaong, quezon, philippines: a vertical integration approach. JITAA 34(3):216-223.

Prasetyo, E., Sunarso, P.B. Santosa, \& Rianto. 2012. The influence of agribusiness subsystem on beef cattle fattening farms profit in Central Java. JITAA 37(2):121126.

Ramdhani, H., S.A. Nulhaqim \& M. Fedryansah. 2012. Peningkatan kesejahteraan petani dengan penguatan kelompok tani. Jurnal Riset 2(3):423-429.

Riszquna, Isbandi, E. Rianto, \& S.I. Santoso. 2014. The analysis of factors affecting the performance in benefits of karapan (racing) cattle business in Madura Island, East Java. JITAA 39(1):65-72.

Roessali, W., S. Masyhuri, Nurtini, \& D.H. Darwanto. 2011. Factors influencing farmers decision to increase beef cattle business scale in Central Java Province. JITAA. 36(1):27-35.

Rustandi, Y. \& R. Suhadji. 2017. Keragaan dan evaluasi fungsi kelembagaan kelompok tani di Kecamatan Papar Kabupaten Kediri Jawa Timur. Jurnal Agrica Ekstensia 11(2):55-60.

Septiani, W., Marimin, Y. Herdiyeni, \& L. Haditjaroko. 2017. Risk based milk pricing model at diary farmers level. Media Peternakan 40(3):218-227.

Setiawan, B. M., Isbandi, P.B. Santosa, \& E. Rianto. 2013. Optimum of lenght of raising time and the relation with business income of simmental - ongole grade cross grade beef cattle fattening farm in Wonosobo Regency, Central Java. JITAA 38(2):109115.

Sumekar, W., Isbandi, U. Atmomar-sono, \& I. Susilowati. 2013. Business performance of duck farmers in brebes regency, Central Java. JITAA 38(3):171-175.

Suswandi \& Sutarno. 2017. Analisa dinamika dan kemandirian kelembagaan ekonomi petani dengan penerapan pertanian organik bersertifikasi di Kabupaten Boyolali. Prosiding Seminar Nasional Progam Studi Bimbingan Konseling, Surakarta 22 Agustus 2017. Hal. 220-240.

Tawaf, R., M. Paturochman, R. Herlina, M. Sulistiyati, \& A. Fitriani. 2016. The optimation of farmers familities revenue the integration of pasundan cattle and paddy farming in West Java. JITAA 42 (4):270-278.

Prasetyo, E., Sunarso, P.B. Santosa, \& Rianto. 2012. The influence of agribusiness subsystem on beef cattle fattening farms profit in Central Java. JITAA 37(2):121126.

Wiyono, G. 2011. Merancang Penelitian Bisnis dengan Alat Analisis SPSS 17.0 \& Smart PLS 2.0. Unit Penerbit dan Percetakan STIM YKPN Yogyakarta. Yogyakarta. 